\title{
Portable Spirometer Using Air Pressure Sensor MPX5500DP Based on Microcontroller Arduino Uno
}

\author{
Syaeful Ilman ${ }^{1}$, Erfiana Wahyuningsih ${ }^{2}$ \\ \{syaeful.ilman@undira.ac.id ${ }^{1}$, erfiana.wahyuningsih@undira.ac.id ${ }^{3}$ \} \\ Elektrical Engineering, Faculty of Engineering and Informatics, Universitas Dian Nusantara, \\ West Jakarta, Jakarta, Indonesia ${ }^{1}$, Elektrical Engineering, Faculty of Engineering and \\ Informatics, Universitas Dian Nusantara, West Jakarta, Jakarta, Indonesia ${ }^{2}$
}

\begin{abstract}
A spirometer is one of medical devices that functions to measure the capacity and volume human lungs. The design of the spirometer consists of several electronic components given as follows. A power supply,MPX5500DP pressure sensor, a noninverting amplifier, a push button, an Arduino Uno Microcontroller and an LCD display.Calibration of the spirometer is done by filing a balloon with $1000 \mathrm{ml}$ of air which is injected from a syringe of $100 \mathrm{ml}$ capacity and needing 10 time injections for $1000 \mathrm{ml}$ of air. Following this step, the $1000 \mathrm{ml}$ air of the balloon is released through the mouth piece. The result displayed by the LCD shows $1073.72 \mathrm{ml}$ instead of $1000 \mathrm{ml}$, indicating 7\% error. The test mode is carried out it 2 stages. The first stage is by maximum inhaling of air for 1 second duration to measure FEV1 (Forced Expiratory Volume 1 second). Similar to the first stage, the test is done for 5 second duration to measure FVC (Forced Vital Capacity). The test results are displayed by LCD and ratio is taken between FEV1 and FVC for each respondent. It is shown the ratio for 6 respondents under test varies between $82.78 \%$ and $94.04 \%$.
\end{abstract}

Keywords: Spirometer, air pressure sensor MPX550DP, Arduino UnoR3, PPI, FVC, FEV.

\section{Introduction}

Health is one of the most important parts of human life. Many people want to have a healthy and fit body. To determine the level of a person's health can be observed from several aspects, one of which is from performance of the respiratory system. In a simple respiration process can be defined as the process exchange of oxygen gas (O2) from the air (atmosphere) with carbon dioxide $(\mathrm{CO} 2)$ and water vapor as residue of oxidation in the lungs.

The lungs are organs of the respiratory system and associated with the blood circulatory system. Less oxygen concentration into body will cause disruption of health system in the human bodyand some diseases such as asthma in respiratory system or anemia in blood circulatory system.In the medical world, Technology has a major influence in diagnosing a patient's health. The level of human lung health can be determined by measuring the volume of respiratory air. The device used to measure air capacity of the lungs known as a spirometer.

Latest research with the title "Pengukuran Volume Paru-ParuDenganMemanfaatkan Sensor Tekanan" In this research using a pressure sensor MPX5100DP. The results of the design of device compared with a spirometer property of a university laboratory.Based on the above research background, so that the author will implement of research which aims to designing a prototype medical instrument that used to measure the volume of $\mathrm{FVC}$ and $\mathrm{FEV}_{1}$ in the lungs using a pressure sensors based microcontroller arduino Uno. [1]

Based on the above research background, so that the author will implement of research which aims to designing a prototype medical instrument that used to measure the volume of FVC and $\mathrm{FEV}_{1}$ in the lungs using a pressure sensors based microcontroller arduino Uno.

\section{Literature Review}




\subsection{Human Respiratory System}

Respiratory is an event breath of air from outside which contains oxygen $(\mathrm{O} 2)$ into the body and exhaled air which contain carbon dioxide (CO2) as residual of oxidation out of the body. [2]

The respiratory system is function to manage exchange of oxygen and carbon dioxide between air and blood. Oxygen is required by all cells to produce a source of energy needed by the body. Carbon dioxide is produced by cells that metabolically active and formed an acid which must be removed by the body.[3]

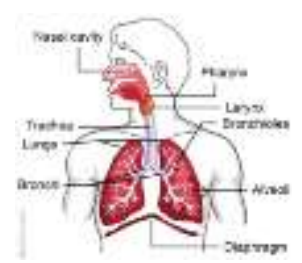

Fig. 1. The Human Respiratory Systems Source:[4]

\subsection{Spirometer}

Spirometer is a device that measures the volume of breathing air that function to determine the condition of the human lungs, while breathing in a certain period of time with recording the amount of air out (expiration) and incoming (inspiration) into human lungs.

Examination of lung function with a spirometer can describe some aspects condition of the lung. FEV1 is an examination that can show obstructive abnormalities in the airway. While FVC will show an abnormality that is restrictive, this could occur due to a reduction in lung tissue function, limited development of thoracic wall or diaphragm movement.

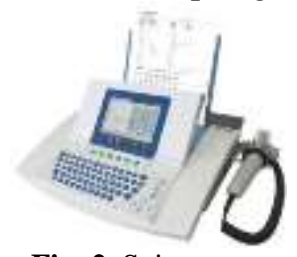

Fig. 2. Spirometer Source : [5]

\subsection{Venturimeter}

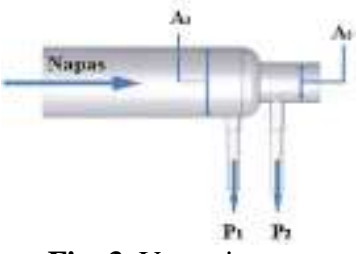

Fig. 3. Venturimeter Source :[6]

Venturimeter is a pipe narrowing. The air flow will be faster if passing through a small crosssectional area in comparison with a large cross-sectional area. The pressure will be greater as it passes through a larger cross-sectional area and the pressure will be smaller if it passes a smaller cross-sectional area in horizontal pipes, $\mathrm{h} 1=\mathrm{h} 2 \mathrm{~h}$, then if the system is applied to the Bernoulli equation.

Based on the continuity equation

$$
P_{1}-P_{2}=\frac{1}{2} \rho\left(V_{2}^{2}-V_{1}^{2}\right)
$$

Obtained equation

$$
Q=A_{1} \cdot V_{1}=A_{2} \cdot V_{2}
$$

$$
V_{2}=\frac{A_{1} \cdot V_{1}}{A_{2}}
$$

Substituting 1 with 3 then we will get the equation 


$$
Q=A_{1} X \sqrt{\frac{\frac{2\left(P_{1}-P_{2}\right)}{\rho}}{\left(\frac{A_{1}}{A_{2}}\right)^{2}-1}}
$$

Fluid flow rate on the first point can be obtained by the equation with $\mathrm{p} 1$ is the pressure on the cross-sectional area is great, $\mathrm{p} 2$ is the pressure on the cross-sectional area is small, $\rho$ is the value of the density of air exhaled, A1 is the cross-sectional area large pipe, and A2 is the cross sectional area of the pipe small. The equation for the fluid flow rate at the second point is obtained.

$$
Q=A_{2} X \sqrt{\frac{\frac{2\left(P_{1}-P_{2}\right)}{\rho}}{1-\left(\frac{A_{1}}{A_{2}}\right)^{2}}}
$$

\subsection{Air Pressure Sensor MPX5500DP}

Air pressure sensor with a strain gauge type pressure sensor MPX5500 is sensitive to low pressure, just by blowing alone can influence the output voltage is generated, this sensor uses Silicon material Stress Gauge Stain.[7]

MPX5500 is a piezoresistive strain gauge type transducer made from silicon that is integrated in a chip, working at a pressure of $0 \mathrm{kPa}$ to $100 \mathrm{kPa}(0$ psi to $14.5 \mathrm{psi})$ or $15 \mathrm{kPa}$ to $115 \mathrm{kPa}(2.18$ psi to $16.68 \mathrm{psi}$ ) with output voltage of 0.2 volts to 4.7 volts.

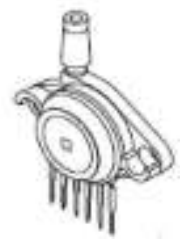

Fig. 4. Components of air pressure sensor MPX5500DP Source : [7]

Table 1. Pin Number of air pressure sensor MPX5500

\begin{tabular}{c|c} 
Pin number & Function \\
\hline 1 & VOUT \\
\hline 2 & Ground \\
\hline 3 & VCC \\
\hline 4 & N/C \\
\hline 5 & N/C \\
\hline 6 & N/C \\
& Source : [7]
\end{tabular}

\subsection{Microcontroller Arduino Uno R3}

The Arduino Uno is a microcontroller board based on the ATmega328 (datasheet). It has 14 digital input/output pins (of which 6 can be used as PWM outputs), 6 analog inputs, a $16 \mathrm{MHz}$ ceramic resonator, a USB connection, a power jack, an ICSP header, and a reset button. It contains everything needed to support the microcontroller; simply connect it to a computer with a USB cable or power it with an AC-to-DC adapter or battery to get started. [8] 


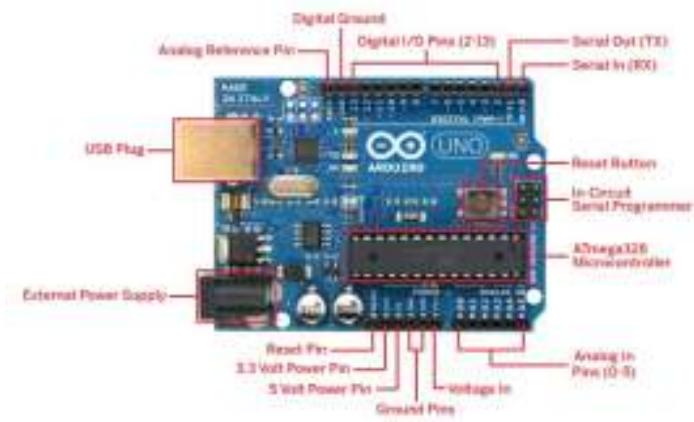

Fig. 5. Arduino Uno Board Source : [8]

\section{Research Methods}

In this section will discuss the design a device consisting of several component parts that are controlled and integrated with one another. In this section, there are three basic parts of the device namely: mouthpieces design, hardware design and software design.

In block mouthpiece describes the preparation of inflatable air tools that will be integrated with the air pressure sensor MPX550DP on input block of hardware design, the hardware block divided into 4 main blocks namely: power supply, input, process and output, the overall design of the system. Meanwhile, in block software program used to explain a coding on microcontroller to manage the entire process so that the system can give the desired output.

\subsection{Design Mouthpieces}

Mouthpiece based on principle venturimeter. The principle is a physics equations of fluidal mechanics in which fluidal flow will be faster if passing sectional area is smaller compared with sectional area is large the pressure is greater, if passing sectional area is large and pressure is smaller if passing sectional area is small.

In the design of mouthpieces authors use designs that have been created by LAS Lapono.[9] On the research study design spirometer, Mouthpieces design is shown in Fig. 10. Using equations 8 venturi effect in the previous chapter with the value $\mathrm{r} 1=1.15 \mathrm{~cm}$ and $\mathrm{r} 2=0.3 \mathrm{~cm}$. then design mouthpieces produce a water flow rate of up to a maximum of $3,79 x 10^{-5} x \sqrt{\Delta P}$ liter.

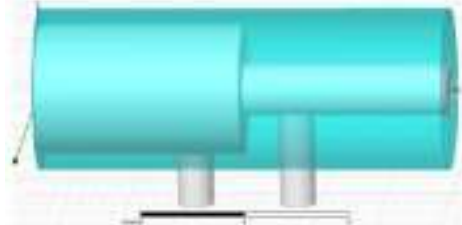

Fig. 6. Design Mouthpiece Source : [9]

\subsection{Hardware Design}

Portable spirometer design using pressure sensor mpx5500dp based arduino Uno. Generally the device design consists of a Power supply is used to supply voltage to overall circuit on the system. Power supply used in this device with a voltage value of 5 volts and 9 volts. Power supply with voltage 5 volt is used as voltage source for air pressure sensor mpx $5500 \mathrm{dp}$, push button and LCD circuit. Power supply with voltage 9 volt is used as a voltage source for arduino uno microcontroller

The mpx5500dp air pressure sensor is used to read the output voltage value from the airflow by the mouthpieces. Furthermore, the value of output voltage will be converted into pressure in Pascal unit. The output voltage value of the air pressure sensor will be gain by a non-inverting amplifier circuit. The gain process in this circuit is made into 11 times. On pushbutton added 
resistor $10 \mathrm{Kohm}$ as pull down on circuits with the aims to avoid undefined signal or floating when pushbutton no pressed. The pushbutton in this design circuits used active high condition.

Microcontroller Arduino Uno has function as master or central data processing and information. Microcontroller Arduino Uno received input data or information from sensor MPX5500DP after gained by non-inverting which will be processed and executed on output block in accordance with command to perform the desired action. And finally data or information sends to the output to turn on LCD(Liquid Crystal Display) based on Arduino LCD library.

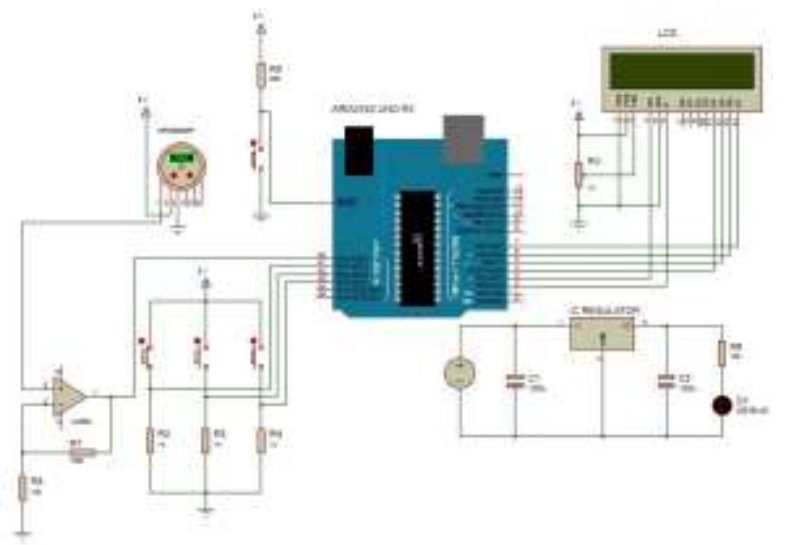

Fig. 7. The Circuit Overall Equipment

Sources : my schematic design (2017)

\subsection{Software Design}

In the block software program used to explain a coding on microcontroller to manage the entire process so that the system can give the desired output. The Flowcharts function to facilitate making a coding of the program and minimize errors in programming.

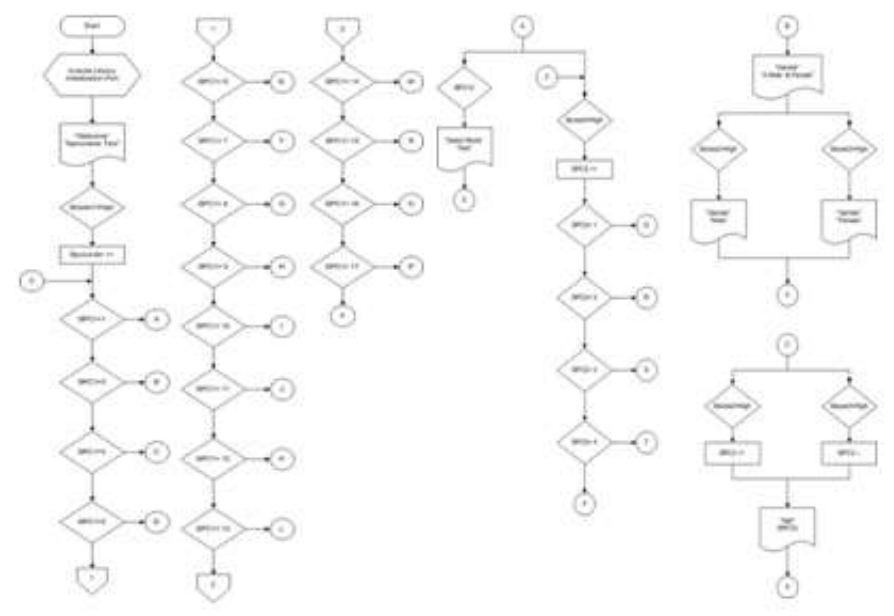

Fig. 8. flowchart programs (1)

Source : my flowchart design (2017) 


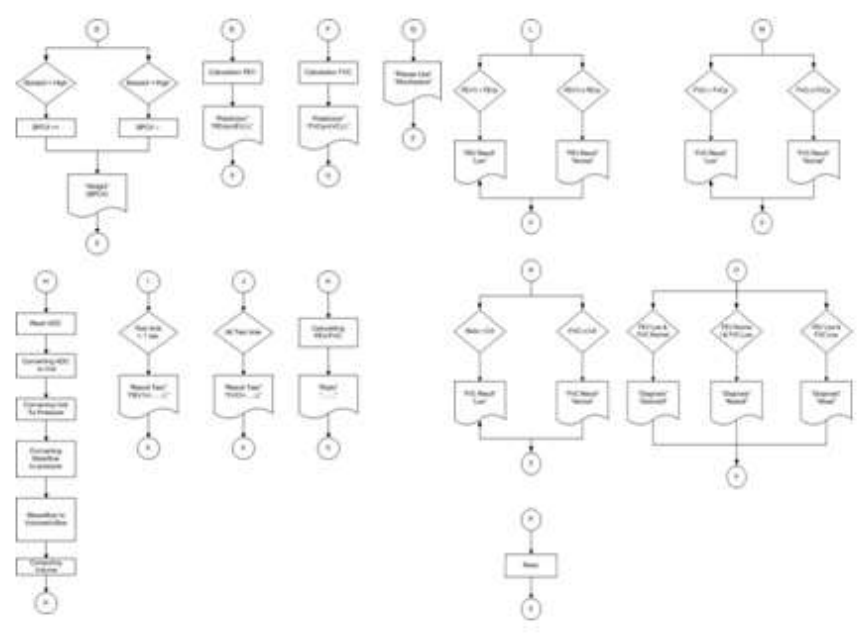

Fig. 9. flowchart programs (2)

Source : my flowchart design (2017)

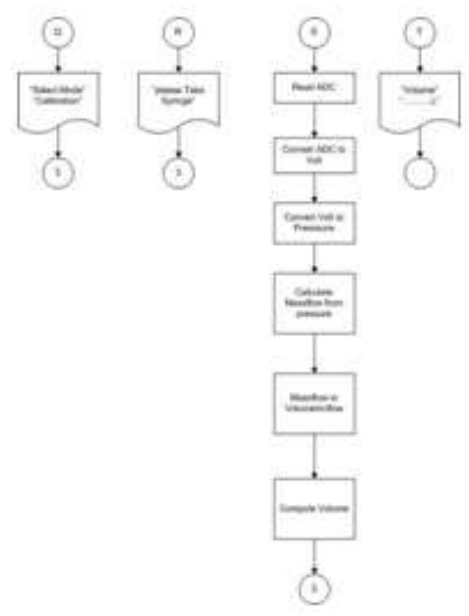

Fig.10. flowchart programs (2)

Source : my flowchart design (2017)

Description program flowchart on Arduino microcontroller shown in the figure is 13 to 15 is as follows:

When the device is switched on, then program will start read library program and initialize ports on the arduino that will be used as input program as well as output program. The first display that will appear on the LCD screen is "Welcome spirometer Test". After that display will show "Select Mode A. Test B.caibrate" on the screen that indicates the user to select a test or calibration mode. Test mode is used to perform measurements the patient breathing volume, while calibration mode is used to calibrate the device using a syringe to determine whether the amount of air volume that readable on the instrument same with the volume of air expelled by the syringe.

\section{a. Test Mode}

If the user wants to perform test mode, the user will press Button State1 and Show display "Test Mode Select" on the LCD screen. Furthermore, in the programming, the user is required to select / enter parameters of the patient such as sex, age and height of the patient. The parameters required to perform diagnostics values $\mathrm{FEV}$ and $\mathrm{FVC}$ of the patient before the examination the display will show prediction FEV and FVC. 
Next program will show the screen "please Use Mouthpiece", which means the user requesting the patient to inhale a deep breath and hold it, and the user ask the patient to put the mouthpiece in his mouth. Furthermore,the user asks patient to blow whole air that had been hold previously until the aspiration weakened or nothing left. When patients exhale the programming started the conversion of breath into the air volume. After airs blowing from the patients are discharged, users permit the patient to release mouthpiecethe display will show the test results FEV1, FVC and ratio of patients on the LCD screen

Next, programming will compare FEV value of test results (FEV1t) with FEV value of prediction results (FEVp), compare $\mathrm{FVC}$ value of test results $(\mathrm{FVCt})$ with $\mathrm{FVC}$ value of prediction results $(\mathrm{FVCp})$, and compare the value Ratio. Furthermore, programming will compares the result FEV and FVC for diagnosing respiratory diseases suffered by the patient.

\section{b. Calibration Mode}

If the user want to do the calibration mode The user would press the button Bstate2, will show display "Calibration Mode Select" on the LCD screen, Next program will show display "please pair the syringe into the mouthpiece" on the LCD screen, which means the user prepares a syringe that has been filled with air. Furthermore, the user is requested to pair a syringe into the mouthpiece. After it done pair syringe into the mouthpiece user presses syringe so that the entire air inside out until nothing left. When the syringe began to remove air, then the programming started conversion from blowing into the air volume.

\section{Result and Analysis}

\subsection{The Overall Test Result}

After experiment each block system. The next, will be conducted experiment on the overall device. The overall experiment conducted by combining all of the block system. The purpose of this test is to determine whether the design of the overall device can work properly or not. As for the overall experiment consist of a calibration mode and the test patient mode. The entire circuit of the block system that has been merged can be seen in the figure 11 .

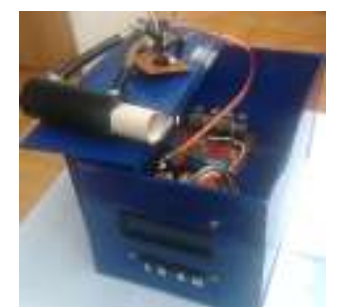

Fig. 11. the overall device spirometry

Source : my testing device (2017)

\subsubsection{Calibrate mode device}

The stages to perform the calibration process are:

a) Set the mode to the tool calibration mode selection.

b) Connect mouthpieces to the sensor.

c) Prepare syringe / balloon that contain the volume of $2000 \mathrm{Ml}$.

d) Attach syringe / balloon to mouthpieces.

e) Push / remove the existing air in the syringe / balloon until no remaining

f) Compare the measured amount of volume in the LCD by the number of issued volume of the syringe.

g) measurement Repeat 3-5 times

The results of calibration measurements can be seen in figures 23 and table 4 . 


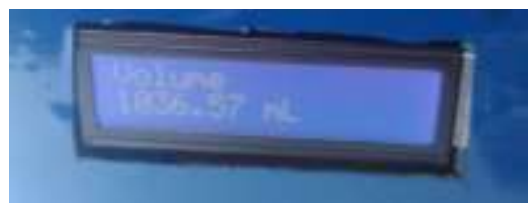

Fig. 12. The calibration mode measurement result Source : my testing device (2017)

Table 2. the result of experimental device at calibration mode

\begin{tabular}{cccc}
\hline Experiment & $\begin{array}{c}\text { Volume } \\
(\mathbf{m L})\end{array}$ & $\begin{array}{c}\text { LCD Display } \\
(\mathbf{m L})\end{array}$ & Error (\%) \\
\hline I & & 1102,75 & 10,27 \\
II & & 1089,76 & 8,98 \\
III & & 1089,67 & 8,97 \\
IV & 1078,97 & 7,90 \\
V & 1000 & 1099,94 & 9,99 \\
VI & & 1083,44 & 8,34 \\
VII & & 1114,39 & 11,44 \\
VIII & 1036,57 & 3,66 \\
IX & & 1029,66 & 2,97 \\
X & & 1012,01 & 1,20 \\
Average & 1000 & 1073,72 & 7,37 \\
\hline
\end{tabular}

Source : my testing device (2017)

From the experimental result in calibration mode show in the above table, The experiment performed 10 times by shooting air of $1000 \mathrm{ml}$ of balloon / 10xsyringe $100 \mathrm{ml}$ into mouthpieces in device at calibration mode, the measured value in LCD range between 1012,01-1114,39 $\mathrm{mL}$ and average error of overall calibration mode is $7,37 \%$.

\subsubsection{Patient Test Mode}

The stages to test the tool on a patient test mode include:

a) Users give an explanation to the patient about the way of doing the test.

b) User asks age, height and gender of the patient.

c) Users invited patients to try to do normal breathing with a mouthpiece.

d) After completing the normal breathing, the test can be done.

e) Set mode device to test patient mode

f) Connect mouthpieces to sensor

g) Users enter data from the patient's personal data (such as age, height and gender) in accordance with the parameters that exist on the appliance

h) Attach the mouthpiece to the mouth

i) Take / breathe air in and maximized through Mouthpiece

j) Breathe the air through the mouthpiece until nothing remains in the oral cavity.

k) Remove the mouthpiece from the patient's mouth

1) User record data coming out of the LCD (such as the value of FEV, FVC and diagnosis of patients)

m) Repeat measurement 3-5 times. 


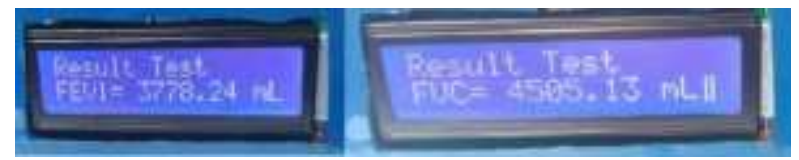

Fig. 13. the test mode measurement result Source : my testing device (2017)

From the experimental results on the instrument test mode patient with experiments conducted on six respondents (4 male and 2 female). Each respondent attempted test 3 times and Summary trials can best be seen in Table 3 .

Table 3 the best experiment result from 6 respondents

\begin{tabular}{|c|c|c|c|c|}
\hline \multirow{2}{*}{ Name } & \multirow{2}{*}{ Gender } & \multicolumn{3}{|c|}{ Test Result } \\
\hline & & $\mathrm{FEV}_{1}$ & FVC & Ratio \\
\hline $\begin{array}{l}\text { Yudhana } \\
\text { Sastriawan }\end{array}$ & Male & 3676,52 & 4441,25 & 82,78 \\
\hline Yusuf Darmawan & Male & 3509,67 & 3960,25 & 88,62 \\
\hline Alam amaludin & Male & 3192,87 & 3779,63 & 84.48 \\
\hline Syaeful Ilman & Male & 3625,15 & 4187,54 & 86,57 \\
\hline Nurul Hijriyati & Female & 2642,53 & 3145,55 & 84,01 \\
\hline Mariyani U & Female & 2840,86 & 3020,79 & 94,04 \\
\hline
\end{tabular}

Source : my testing device (2017)

\subsection{A Comparison analysis the results of experiments on devices with lab test results}

In this section will be discussed a comparative analysis of results of experimental tests on devices with laboratory results. The author conducted a laboratory test in advance as a reference of making the tool this spirometer. After making spirometry device have completed, author will compare the results with laboratory results. Whether, the results of the experiment instrument in accordance with the laboratory results.

Comparison of this experiment based on test results author (respondent 4) in the laboratory "PRODIA KRAMAT" with the results of test tools that have been created. Comparison of experimental results with the results of laboratory instruments can be seen in Table 6.

Table 4 Comparison of the overall results of experiments tools with laboratory results

\begin{tabular}{cccc}
\hline $\begin{array}{c}\text { Parameter } \\
\text { Test }\end{array}$ & LaboratoryResults(mL) & $\begin{array}{c}\text { Average } \\
\text { results } \\
\text { forTest } \\
\text { Device(mL) }\end{array}$ & $\begin{array}{c}\text { Error } \\
(\%)\end{array}$ \\
\hline FEV1 & 3770 & 3563,27 & 5,48 \\
FVC & 4020 & 4086,74 & 2,17 \\
FEV1/FVC & 93,78 & 87,19 & 7,03 \\
\hline
\end{tabular}

Source : my testing device (2017)

Based on the comparison results of laboratory tests with test tool as shown in Table 6. With a difference of error results obtained from this comparison, it can be concluded that the results of experimental tools that have been made in accordance with the function of a laboratory instrument. 


\section{Conclusion}

Based on the results of device testing, it is concluded of the following:

1. The design of "portable spirometer using air pressure sensor mpx5500dp based on arduino uno microcontroller" has been successfully implemented and function properly in accordance with the program. the components of spirometer consist of mouthpiece, air pressure sensor mpx550dp, non-inverting circuits using ICLM358, arduino uno microcontroller board and LCD display.

2. In calibration mode the display read by LCD shows average $1073,72 \mathrm{ml}$ in stead of $1000 \mathrm{ml}$, this gives $7,3 \%$ error

3. The highest ratio betweeen FEV1 and FVC from 6 respondent ( consisst of 4 male respondent and 2 female respondent) is: 88,62\% for male and 94,04 for female.

\section{Reference}

[1] A. ZAINUDIN, "Pengukuran volume paru-paru dengan memanfaatkan sensor tekanan," Inov. Fis. Indones., vol. 4, no. 3, 2015.

[2] B. A. C. Syaifuddin, "Anatomi Fisiologi untuk Siswa Perawat," EGC. Jakarta, 1997.

[3] E. J. Corwin and B. S. Patofisiologi, "Edisi 1," Jakarta EGC, 2001.

[4] "body anatomi.".

[5] Carefusion, "Digital Spirometer.".

[6] Unknown, "Venturimetri.".

[7] DataSheet MPX5500DP, "Freescale Semiconductor Integrated Silicon Pressure Sensor On-Chip Signal Conditioned, Temperature Compensated and Calibrated," Sensors (Peterborough, NH), pp. 2007-2009, 2009.

[8] Arduino.cc, “Arduino Uno,” 2016. .

[9] L. A. S. Lapono and A. Harjoko, "PERANCANGAN SPIROMETER MENGGUNAKAN SENSOR TEKANAN MPX2010DP.” [Yogyakarta]: Universitas Gadjah Mada, 2011. 